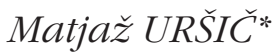

\title{
PANDEMIJA COVIDA-19 KOT NADALJEVANJE PROCESOV FLEKSIBILIZACIJE IN PREKARIZACIJE DELOVNIH RAZMER ZA KREATIVNE POKLICE V SLOVENIJI**
}

\begin{abstract}
Povzetek. Ob analizah kreativnih dejaunosti se pogosto pojavljajo problematična opažanja delounih procesov zaposlenih $v$ teh poklicih. Kreativni delavci so s tega vidika dojeti kot zelo prilagodljivi glede na način, kraj in plačilo dela. Zaradi tourstnih značilnosti, ki jih ne uvrščajo med tradicionalne, tj. gospodarsko in socialno bolj stabilne oblike zaposlitve, lahko predvidevamo, da so bili kreativni delavci med najbolj prizadetimi zaradi pandemije Covida-19. Članek na podlagi podatkov iz longitudinalne raziskave "Slovenski kulturno-kreativni delavec v času Covida-19" (2020) najprej analizira vplive pandemije na širši kreativni sektor, nato pa prek analize sprememb $v$ delovnem procesu in življenjskih razmerah kreativnih delavcev identificira elemente prekarizacije po posameznih podsektorjih, kot so na primer vizualne, uprizoritvene umetnosti ali glasba. Pri tem ugotavlja, da pandemija v večini segmentov kreativnih poklicev nadgrajuje obstoječe oblike prekarizacije.
\end{abstract}

Ključni pojmi: pandemija Covida-19, fleksibilizacija, prekarizacija, kreatione industrije, kreativni delavec

Uvod

Kreativne dejavnosti, ki jih pogosto umeščamo med kreativne, kulturne ekonomije ali kreativne industrije, postajajo vse pomembnejši segment urbanih gospodarstev in zaposlujejo vse več ljudi (Landry in Bianchini, 1995; Bairoch, 1998; Scott, 2000). Standardne definicije kreativnih industrij se povečini nanašajo na različne aktivnosti, ki prek generiranja ali uporabe znanja, informacij producirajo ekonomske učinke. Pri tem se kreativne industrije povečini povezuje s kreativnimi poklici, ki neposredno generirajo specifične tipe kreativnih produktov, in ne s celotno verigo dejavnosti,

* Dr. Matjaž Uršič, izredni profesor, Fakulteta za družbene vede, Univerza v Ljubljani, Slovenija.

** Izvirni znanstveni članek. DOI: 10.51936/tip.58.3.762-784 
ki so pripomogle h končnemu izdelku. S tega vidika po mnenju nekaterih avtorjev (Cunningham in Higgs, 2009; Cunningham, 2013; Hearn, 2014) najdemo kreativne delavce $\mathrm{v}$ vseh delovnih sektorjih in ne le $\mathrm{v}$ kreativnih industrijah. Prav zaradi tega je pomen kreativnih dejavnosti bistveno širši od relativno ozkega pojma ter pomeni da je $\mathrm{v}$ kreativni proces, tj. izdelavo kreativnih produktov, vpeto večje število ljudi in širši sklop gospodarstva, kot se zdi na prvi pogled.

Po podatkih Združenih narodov (2019) kreativna gospodarstva na globalni ravni predstavljajo 3\% celotnega bruto družbenega proizvoda (BDP), zaposlujejo prek 30 milijonov ljudi in zagotavljajo več delovnih mest delavcem, starim od 18 do 25 let, kot katera koli druga področja zaposlitve. V Evropski uniji zagotavljajo prek pet milijonov delovnih mest, samo v Sloveniji delež zaposlenih v kreativnem sektorju predstavlja $7 \%$ vseh delovno aktivnih, ki ustvarijo skoraj tri milijarde evrov prometa (IER, 2017; Matjaž et al., 2020), kar priča o izjemnem pomenu tega sektorja za delovanje ekonomije. Po podatkih zavoda BIG (2020) je v Sloveniji samo na področju poklicev, kot so kreativni in nastopajoči umetniki, avtorji, novinarji in jezikoslovci, zaposlenih približno 12.000 ljudi, pri čemer delež samozaposlenih med njimi znaša $40 \%$. Število podjetij v kulturnem sektorju je 9.360, medtem ko naj bi bil delež vseh registriranih organizacijskih enot, ki jih zavzema kreativno-kulturni sektor v Sloveniji, 10,5\% (Matjaž et al., 2020). Pri tem med gospodarskimi subjekti vanj sodi $8,4 \%$ vseh aktivnih podjetij v slovenskem gospodarstvu. Med letoma 2000 in 2011 se je obseg kreativnega razreda v Sloveniji povečal za $27 \%$ (Kozina, Clifton, 2019). Pri tem se je $\mathrm{v}$ istem obdobju v predelovalnih dejavnostih delovna sila zmanjšala za $30 \%$, število delavcev v storitvenih dejavnostih in kmetijstvu pa stagniralo. Te sektorske spremembe $\mathrm{v}$ slovenskem gospodarstvu so jasen pokazatelj prehoda $\mathrm{v}$ »družbo kreativnega znanja«, večinoma na račun deindustrializacije (Kozina, Clifton, 2019: 148).

Sektor kreativnih gospodarstev je bil v predpandemičnem obdobju zelo aktiven in je hitro rasel. Z naraščanjem števila kreativnih delavcev so se kreativne industrije promovirale kot dragoceno orodje za diverzifikacijo lokalne gospodarske osnove in nadomeščanje izgubljenih delovnih mest $\mathrm{v}$ tradicionalnih industrijskih in storitvenih sektorjih (Howkins, 2001; Florida, 2002; Hesmondhalgh, 2002). Obenem je treba poudariti, da zagovorniki prehoda $\mathrm{v}$ digitalno podprto družbo znanja pogosto brez zadostnega premisleka spodbujajo vse večji delež zaposlenih v kreativnih industrijah, ob tem pa posledice in vplivi tega sektorskega premika na delovne razmere niso dobro analizirani. Po mnenju različnih avtorjev (von Osten, 2007; Raunig in sod., 2011; Minichbauer, 2011; Kuster in Tsianos, 2011) je diskurz, ki spodbuja kreativnost in podjetništvo kot nova ekonomskega rešitelja, dobil značilnosti mita, ki mistificira prijetne plati kreativnih zaposlitev, po drugi strani 
pa zanemarja ali prezre stransko škodo, povzročeno s sočasno prekarizacijo delovnih razmer.

Ena izmed ključnih značilnosti kreativnih zaposlitev temelji na njihovi fleksibilnosti. Skupine kreativnih delavcev, ki se ukvarjajo s pretežno nematerialnimi, mentalno zahtevnimi in organizacijsko zapletenimi dejavnostmi, so zabeležile izrazit prehod v fleksibilno delovno okolje, ob čemer je fleksibilizacija dela teh nadarjenih in pogosto visoko izobraženih kadrov zaznamovana z zahtevnimi in individualno oblikovanimi delovnimi urniki, nizkimi in nerednimi plačili ter visoko stopnjo potencialnega tveganja ob izrazito deprivilegirani (podrejeni) delovni poziciji v odnosu do delodajalca. Avtorji, kot so Hardt in Negri (2004) ter Virno (2004), ob tem ugotavljajo, da se je prekarni pol v tem pogledu razširil iz obrobnih, izobraževalno nezahtevnih delovnih mest na nekdaj stabilna jedrna delovna mesta visokokvalificiranih strokovnjakov na področju produkcije znanja. Na trgu dela je v obdobju zadnjih dveh desetletij zaznati trend naraščanja potreb po fleksibilni kreativni delovni sili, kar je privedlo do oblikovanja zelo specifičnih zaposlitvenih skupin, ki so bile predtem vpete v precej bolj stabilna delovna okolja. Posamezne skupine kreativnih delavcev so se v navedenem obdobju postopoma dohodkovno izenačile s skupinami delavcev v pretežno manj 764 zahtevnih manualnih službah nizkega cenovnega razreda, ki delajo po formaliziranih monotonih urnikih in normativih zaposlovanja.

Pandemija Covida-19 je še dodatno zarezala v obstoječo strukturo delovnih razmerij kreativnih zaposlenih in povzročila izredne transformacije načina dela, kreativnega procesa, produkcije in življenjskega sloga, ki je bil značilen za področje kreativnih industrij. Članek bo analiziral radikalne spremembe na področju kreativnih industrij, ob čemer se zdi, da se procesi fleksibilizacije in prekarizacije kreativnih zaposlitev v razmerah pandemije nadaljujejo ali celo stopnjujejo, vendar pod drugačnimi pogoji, kot so bili značilni za obdobje pred pandemijo. S tega vidika je pandemija vplivala na: a) zaposlitvene pogoje kreativnih poklicev b) naravo izvajanja poklicnih nalog in c) sam kontekst izvajanja poklicnih nalog. Na podlagi podatkov iz longitudinalne raziskave "Slovenski kulturno-kreativni delavec $\mathrm{v}$ času Covida-19«(Matjaž et al., 2020) se bomo osredotočili zlasti na kontekst zaposlitvenih pogojev in primarno preverili, kako je pandemija Covida-19 vplivala na različne kreativne poklice, delovne skupine, podsektorje ter na izvajanje kreativnega dela in kakšne potencialne posledice ima to za delovanje družbeno-ekonomskega sistema Slovenije. Ključno raziskovalno vprašanje članka je, ali se je prek uvajanja fizične distance predrugačilo tudi življenjsko okolje in posledično delovni procesi pri kreativnih posameznikih na način, ki vodi v nadgradnjo obstoječih oblik kreativnih prekarnosti. Pri tem so morali kreativni zaposleni svoj delovni proces in razgiban življenjski slog zaradi učinkov pandemije hipno nadomestiti z različnimi 
oblikami samoizolacionizma, posredne komunikacije. Preverjali bomo, ali ni pandemija vplivala samo na upad obsega dela kreativnih zaposlenih, temveč je - še pomembneje - sprožila omejevanje visoke fizične mobilnosti, udejstvovanja v nizu prostočasnih kulturnih, umetniških ali rekreacijskih dejavnostih, kar je paraliziralo utečene oblike življenjskega sloga oz. nezmožnosti aktivacije osnovnega socialnega kapitala posameznih skupin kreativnih posameznikov, posledično pa je generiralo naraščajočo prekarizacijo tovrstnih zaposlitev. In nenazadnje, nove pandemične razmere poleg mikro vplivov na vsakdanje življenje kreativnih posameznikov vplivajo tudi na spremembe v širšem kreativnem ekosistemu Slovenije, pri čemer je še prezgodaj govoriti o dolgoročnih učinkih pandemije na celoten kreativni sektor, lahko pa analiziramo učinke pandemije po posameznih kreativnih podsektorjih in iz njih ekstrapoliramo potencialne dolgoročne trende, ki bodo imeli posledice za celoten družbeno-ekonomski razvoj Slovenije.

\section{Spirala prekarizacije kreativnih zaposlenih med pandemijo Covida-19}

Pandemija je v kontekstu kreativnih zaposlitev povzročila dodatno zaostrovanje delovnih pogojev, ki so že pred izbruhom veljali za izredno problematične. Mnoge kreativne zaposlitve se namreč povezuje z različnimi oblikami »fleksploatacije» (Gray, 2004: 3) in »samoprekarizacije« (Uršič et al., 2018: 841), ki kažejo na izoblikovanje zelo specifičnega življenjskega sloga s sicer visoko stopnjo neodvisnosti in prilagodljivosti, vendar tudi pogostimi »bulimičnimi karierami« (Pratt, 2002), pri čemer posamezniki prehajajo med vzorci razcveta in propada, delo lahko poteka dolge dneve in noči, temu pa sledi obdobje intenzivnega iskanja naslednje kratkoročne zaposlitve (Kong, 2011). Fleksploatacijo lahko opredelimo kot obliko izkoriščanja razmer izjemne prožnosti trga zaposlitev s strani delodajalca, medtem ko samoprekarizacijo označuje prostovoljno sprejemanje pogojev fleksploatacije s strani zaposlenih, ki v tovrstni prožnosti trga dela vidijo tudi določene prednosti. Številne nacionalne vlade in globalne institucije (glej npr. DCMS, 2001; UCLG, 2008; EU, 2010) skušajo popularizirati zaposlovanje v kreativnih gospodarstvih kot obliko poti samorazvoja (Ross, 2009). Kreativne zaposlitvene ustanove, karierni centri, spletne platforme in uradne publikacije mladim diplomantom pogosto svetujejo, naj "si upajo tvegati s prijavo na prostovoljna delovna mesta in neplačano prakso, da bi si pridobili zelo iskane delovne izkušnje« (Ferreri in Graziano, 2014: 3). Ta priljubljeni diskurz nakazuje, da morajo biti zaposleni »kreativni, ne glede na delovno mesto« (von Osten, 2007: 52), ker bo le proaktivno sodelovanje posameznikom omogočilo, da izboljšajo svoje delovne spretnosti in tekmujejo na trgu dela. Poleg tega so samostojni podjetniki, ki združujejo kratkoročne 
pogodbe, začasno delo, krajši delovni čas, samozaposlitev in druge vrste prilagodljivega dela, pogosto predstavljeni kot možnost za povečano delovno avtonomijo, ko - namesto da bi delali za nekoga drugega - postanete svoj šef, ki »dela zase in ne jemlje dela od drugih« (Gunnell in Bright, 2011: 1).

Opisani delovni proces lahko $\mathrm{v}$ kratkem času preide od podobe samorazvoja do prostovoljne prekarizacije, če dostop do finančnih virov, informacij in stabilnih delovnih razmer ni mogoč v daljši časovni perspektivi. S tega vidika se prekarizacija kreativnih delavcev pogosto uresničuje s samoprekarizacijo, pri čemer se boljše plačilo, socialna stabilnost in ustrezni delovni pogoji prenesejo v nedoločeno prihodnost. Medtem ko je standardno razumevanje prekarizacije delodajalcu (tj. lastniku ali upravitelju podjetja) pripisovalo odgovornost za pomanjkanje načrta, pojav nestabilnosti v smislu varnosti delovnega mesta ter materialne ali psihološke blaginje, gre samoprekarizacija še korak dlje. Samoprekarizacija namreč veliko bolj poudarja »osebno odgovornost « zaposlenega, delodajalec pa pričakuje, da se bo delavec »samoreguliral in prakticiral »neodvisnost na osebni ravni« (Lorey, 2011: 85 ). Samoprekarizacija temelji na močnih motivacijskih dejavnikih, ki kreativne delavce nežno silijo v neoptimalen delovni odnos.

Samoprekarizacija kreativnih zaposlenih temelji zlasti na treh značilnostih, ki jih lahko opredelimo kot jedrne značilnosti kreativnega življenjskega sloga in so pomembne tudi za nadaljnjo analizo kreativnih dejavnosti $\mathrm{v}$ obdobju pandemije Covida-19. Prva značilnost življenjskih stilov kreativnih zaposlenih vključuje dejavnik delovne avtonomije. Doseganje delovne avtonomije je običajno dolgoročen pripravljalni proces, ki vključuje kopičenje izkušenj, virov in socialnih omrežij, ki omogočajo stabilizacijo oz. standardizacijo delovnega procesa. $\mathrm{V}$ razmerah fleksibilizacije trga dela, na katerem podjetja zlahka dostopajo do delovne sile in znižujejo posredne stroške dela, tega postopka dolgotrajne delovne priprave in učenja ni več. Tržna tveganja se neposredno prenašajo na delavce, zato se nekateri kreativni delavci raje odločajo za tveganje in samozaposlitev, ki dopušča možnost »ustvarjanja boljših načinov življenja, kot ga imajo najeti delavci« (Bologna, 2007: 1).

Drugo značilnost kreativnih življenjskih stilov predstavlja dejavnik neformalnosti, trendovstva ali "hipsterstva« $\mathrm{v}$ delovnih in življenjskih odnosih (Lorentzen, 2007; Horning, 2010). Delovna avtonomija je namreč zelo povezana z željo po večjem nadzoru nad svojim časom in svobodo pri delu ter v življenju. Zavestno zavračanje običajne delovne rutine krepi podobo delovne avtonomije in omogoča oblikovanje novih eklektičnih življenjskih slogov in delovnih urnikov. Zavračanje standardnih delovnih rutin vključuje tudi predpostavljeno spremembo stopnje formalnosti v odnosih na delovnem mestu (Kuster in Tsianos, 2011). Fleksibilizacija dela je resnično povečala raven neformalnosti na delovnem mestu, tj. doma ali znotraj večnamenskih skupnih, so-delovnih prostorov, "geek« hiš, ki vključujejo različnih 
oblike kohabitacije kreativnih posameznikov, in drugih prostorov, ki omogočajo socialno mreženje med kreativnimi skupinami. Neformalni način komunikacije med kreativnimi delavci na delovnem mestu ponuja podobo izenačevanja in razpuščanja togih hierarhij, ki so obstajale $\mathrm{v}$ fordističnem obdobju, čeprav je delovna hierarhija med delodajalci ali lastniki ter zaposlenimi ostala enaka. Še več, plačnik kreativne delovne sile si pridržuje pravico, da narekuje raven komunikacije, ki se ji zaposleni prostovoljno podredijo, če si želijo službo (Lorey, 2011).

Tretji dejavnik je strah, saj ga fleksibilizacija dela - kljub temu da ustvarja nove priložnosti za kombiniranje delovnih in življenjskih razmer - ne odpravlja. Nova paradigma produktivnosti lahko vključuje neformalnost, vendar kreativne delavce postavlja tudi v skrajno nedoločenost glede plačila, trajnosti zaposlitve, obsega dela in zakriva občutek strahu. Nestabilnost delovnega procesa sili kreativne zaposlene k še večjemu delu. Kuster in Tsianos (2011: 93 ) navajata, da širok dostop do trga omogoča enako fleksibilnost vsem, zato so "zahteve po spretnostih in sposobnostih subjektov takojšnje in enake«, kar ima za posledico povečanje tekmovalnosti in produktivnosti. Pri tem se strah, ki ga uvaja fleksibilizacija dela, prevede oz. zakodira kot užitek skozi filter delovne in življenjske avtonomije, kar kreativnemu delavcu zagotavlja začasno zadovoljstvo. Takšne razmere fleksibilizacije ustvarjajo "precog" (de Peuter, 2011: 421), ki ga opredelimo kot nestandardnega kognitivnega delavca s prestižnim poklicem, ki dela v negotovih razmerah, prikriva strah ter obenem navzven projicira "moč, ki pa za patino svoje arogance prikriva tesnobe zajca, ujetega v past« (De Carolis, 1996: 42).

Način dela $\mathrm{v}$ kreativnih dejavnostih se je $\mathrm{v}$ predpandemičnem obdobju povezoval s specifičnim življenjskim slogom, ki je služil kot nadomestilo oz. substitut za prekarno delovno razmerje. Ob tem je kreativni zaposleni razumel pomanjkljivosti tovrstnih zaposlitev, ki pa jih je kompenziral z všečnim dinamičnim stilom: napetosti in problematične delovne prakse so se sproščale prek različnih dogodkovnih in komunikacijskih kanalov razvejanih kreativnih socialnih omrežij. Pandemija Covida-19 je odpravila številne prednosti tovrstnega kreativnega življenjskega sloga (npr. eklektičen življenjski stil, vpetost $\mathrm{v}$ prostorsko-fizična socialna omrežja, kreativni milje), ob čemer so določene fleksibilnosti in problemi prekarizacije kreativne sfere - v okviru dela na daljavo (teledela) in novih digitalnih komunikacijskih sredstvih - ostali. Narava dela se $\mathrm{v}$ tem pogledu za določene tipe kreativnih podsektorjev (npr. produkcija programske opreme, založništvo itd.), ki delajo na daljavo, na videz ni veliko spremenila, a je treba opozoriti, da je odprava prostorsko-fizičnega konteksta, $v$ katerega so bile položene te dejavnosti, vplivala na pomembne spremembe tudi na teh področjih. Kreativne dejavnosti so s holističnega vidika del širšega kreativnega ekosistema, v katerega so povezani oz. črpajo, izmenjujejo določene informacijske, idejne, prototipne 
zasnove in resurse tudi drugi kreativni sektorji in ostalo gospodarstvo. Z ukinjanjem zmožnosti implementacije oz. prakticiranja teh povezav problematika pandemije Covida-19 v povezavi s kreativno produkcijo pravzaprav postane problematika zaviranja razvoja kreativnega "miljeja« (Meusburger, 2009), v katerega so vpeti kreativni akterji. Če kreativni ekosistem lahko opredelimo kot »okolje, ki prek specializiranih načinov izmenjave, interakcije in komuniciranja med ljudmi in njihovim ekonomskim, socialnim in kulturnim kapitalom podpira kreativne dejavnosti« (Rivas, 2011: 4), je kreativni milje njegov ključni sestavni del in vključuje »mikro socialni kontekst, ki zajema ljudi in njihov odnos do socio-kulturnega sistema, okolja in lokalne skupnosti« (Uršič in Imai, 2020: 8). Kreativni milje se s tega vidika povezuje s celotnim produkcijskih sistemom mesta ali države in vanj integrira tudi komponente partikularno lokalnega (kontekstualno) vezanega znanja, ki se zdi na prvi pogled zdi nepomembno, vsakdanje in na videz ločeno od ekonomske sfere (Pratt, 2004; Florida idr., 2006). Z drugimi besedami: ekonomski in produkcijski sistemi, ki se med drugim napajajo tudi iz kreativnih resursov od spodaj navzgor, tj. prek kreativnih miljejev (Colomb, Novy, 2018), lahko ob dolgotrajni pandemični prekinitvi tovrstne produkcije naletijo na težave, ki jih ne more nadomeščati virtualna interakcija prek digitalnih komunikacij768 skih sredstev. V vrsti študij (Giaccardi in Fischer, 2008; Sailer, 2011; Fischer, 2013) se namreč opaža da je "socialna kreativnost" (Montuouri in Purser, 1997; Long in Pang, 2015) pogosto spregledana komponenta študij razvoja kreativnih dejavnosti, ki se preveč vežejo na končni produkt, medtem ko je kontekst oz. okolje, v katerem je prišlo do tega procesa, postavljen v drugi plan ali celo spregledan. Digitalna orodja, ki pomagajo pri brezstični komunikaciji, organizaciji dela, izmenjavi resursov, s tega vidika pomembno pripomorejo k izvajanju produkcijskega procesa in nedvomno lajšajo učinke pandemije na kreativni sektor. Kljub temu pa ta orodja ne morejo nadomeščati fizično-kontekstualnih lastnosti prostorskih miljejev, ki zagotavljajo določeno »družbeno produkcijo prostora» (Lefebvre, 1991: 299), ki je sestavljeno iz akumulacije prostorskih izkustev, emocij, spomina in drugih kvalitativno ambientalnih značilnosti prostora, ki ustvarjajo kakovost bivanja kreativnih posameznikov.

Pri analizi vplivov pandemičnih razmer na kreativni sektor je s tega vidika potrebno ločevati med »kreativno sposobnostjo in kreativno zmogljivostjo» (Lazaretti, 2012: 2). Obe kategoriji se opirata na časovno dimenzijo, pri čemer sposobnost pomeni moč, da se izvede neko dejanje zdaj, zmogljivost pa se nanaša na to, kar bi se lahko dolgoročno izvedlo prek zorenja (nabiranja izkušenj, kumulativnih učinkov), izobraževanja in interakcije med komponentami v sistemu (True, 1966; Klausmeier, 1961). In prav na osnovi tega razločevanja je mogoče analizirati pomembne spremembe v statusu in delovnih razmerjih kreativnih zaposlenih v obdobju pandemije. Posamezni 
kreativni podsektorji so prek teledela začasno ohranili del svojih kreativnih sposobnosti med pandemijo, medtem ko so podsektorji, kot so npr. gledališče, film ali druge uprizoritvene umetnosti, v tem pogledu začasno izgubile velik del svoje kreativne sposobnosti. Vsem kreativnim podsektorjem pa je skupna izguba določenih dolgoročnih podlag za nadaljnji razvoj kreativnih zmogljivosti. Z omejevanjem delovanja prostorskega kreativnega miljeja se je namreč začela transformacija določenih delov kreativnega sektorja, ki se je še pospešila $z$ hitrejšim uvajanjem digitalnih orodij. Pri tem se odpira veliko vprašanj glede nadaljnjega razvoja kreativnega sektorja, kreativnega ekosistema, potencialne homogenizacije kreativnih dejavnosti in kaj to pomeni za razvoj celotnega spektra drugih ekonomskih dejavnosti, ki so povezane $s$ kreativnim sektorjem. V članku teh obširnih vprašanj zaenkrat ni mogoče nasloviti, mogoče pa je identificirati in analizirati potencialne medpandemične nastavke, posamezne značilnosti in elemente nadaljnjega razvoja kreativnih zmogljivosti kreativnega ekosistema Slovenije.

\section{Analiza kreativnih dejavnosti v obdobju pandemije}

\section{Viri in metodologija}

Analiza kreativnih dejavnosti je težavna naloga že v običajnih okoliščinah, razmere pandemije pa to težavnost še nadgradijo zaradi povečane samoizolacije. Problem sedanjih metodologij, ki poskušajo preučevati kreativne ekonomije, je zbiranje podatkov, povezanih s kreativnimi delavci, ki se pojavljajo $\mathrm{v}$ zelo raznolikih in kompleksnih delovnih procesih. Zaradi težav pri pridobivanju podatkov in določanju stanja kreativnih delavcev v obdobju pandemije se članek osredinja na zelo razpršen vzorec kreativnih delavcev, ki so del produkcijskega procesa temeljnih kreativnih industrij. Vzorec torej temelji na t.i. naključnostnem vzorcu zaposlenih glede na poklice $\mathrm{v}$ kreativnem sektorju po standardni klasifikaciji dejavnosti (SKD, 2008). Pri tem analiza ne vključuje podatke za vse tipe zaposlenih s kreativnega področja, temveč se omeji na najpogostejše zaposlitve, ki so bili zajeti prek naključnostnega vzorca na območju celotne Slovenije in vključujejo področja, kot so npr. film, fotografija, raziskave in razvoj, uprizoritvene umetnosti, glasba, mediji, kreativni turizem, storitveno oblikovanje, razvoj programske opreme in računalništvo itd. (slika 1). Naključnostni vzorec se je oblikoval po principu snežne kepe, pri čemer so začetni postopki nabora vprašalnikov potekali prek spletnih socialnih omrežij institucij, partnerskih organizacij, nevladnih organizacij in digitalnih platform, ki delujejo na področju kreativno-kulturnega sektorja v Sloveniji.

Podatke smo pridobili v okviru raziskave z naslovom "Slovenski kulturno-kreativni delavec v času Covida-19« (Matjaž et al., 2020), v kateri je bilo 
v dveh časovnih točkah (maj 2020 in oktober 2020) zajetih 1521 in 1578 slovenskih delavcev, delujočih na vseh podpodročjih kulturno-kreativnega sektorja, ki so se odzvali vabilu in rešili vprašalnik, ki je obsegal 55 vprašanj (od tega 5 vprašanj odprtega tipa, 13 pa kombiniranih).

\section{Slika 1: RAZPOREDITEV ZAPOSLENIH V KULTURNO-KREATIVNEM SEKTORJU GLEDE NA DEJAVNOST (V\%)}

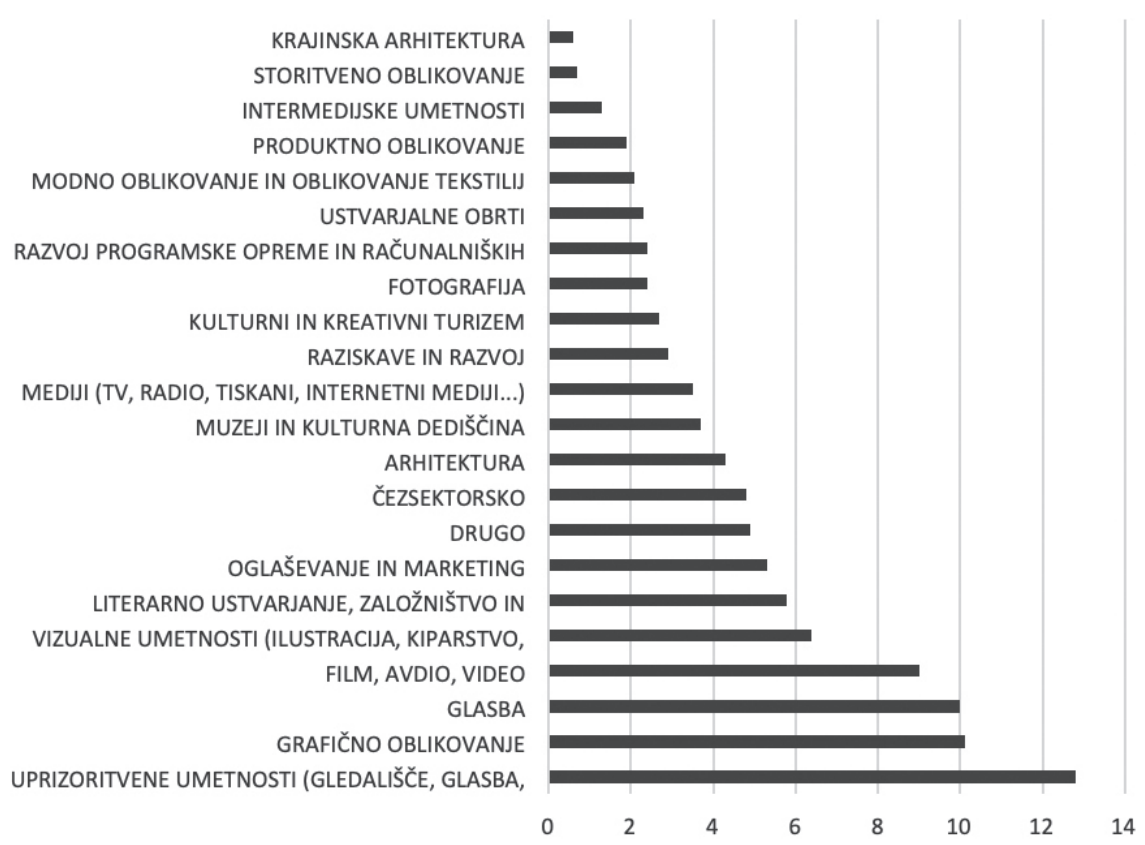

Vir: Matjaž et al., 2020.

Analiza podatkov v članku kombinira različne vrste kvantitativnih in kvalitativnih podatkov z namenom prikazovanja ključnih sprememb, ki so se zgodile zaradi vplivov pandemije. Združevanje različnih metodoloških pristopov je podobno pristopu "mešane raziskovalne metodologije" (Tashakkori in Teddlie, 2010) oziroma "utemeljitvenemu teoretičnemu pristopu (Grounded theory (op. p.))«(Holt-Jensen, 1988; Glaser, 1998) pri razvoju raziskovalnega procesa. Raziskovalni pristop s pomočjo utemeljitvene teorije predpostavlja uporabo večplastnih podatkov s terena, na podlagi katerih se identificira ključne trende in koncepte, ki lahko pojasnijo značilnosti, ki se odražajo v spremembah delovanja kreativnih dejavnosti v obdobju pandemije. S tega vidika metodološki aparat za potrebe analitičnega procesa uporablja nabor podatkov iz vprašalnikov raziskave, ki vključujejo vprašanja zaprtega in odprtega tipa oz. tako statistične podatke kot 
opisne, polstrukturirane odgovore, ki se približujejo intervjujem. Značilnosti vsakega uporabljenega niza podatkov so podrobneje razložene v posebnih razdelkih izbranih analiz.

\section{Analiza vpliva pandemije na kreativne podsektorje}

Na podlagi podatkov iz raziskav v medpandemičnem obdobju bomo najprej analizirali razmere na področju kreativnih dejavnosti in ponazorili, kako je pandemija vplivala na naraščanje prekarizacije in zaposlitvenih neenakosti. Pandemija ni enako vplivala na vse kreativne podsektorje oz. podpodročja. Vrsta podatkov iz raziskave (Matjaž et al., 2020) kaže, da je pandemija imela največji vpliv na podsektorje filmskih in avdio-vizualnih ustvarjalcev, delavcev na področjih uprizoritvenih umetnosti, glasbe, fotografije in kulturno-kreativnega turizma. Na sliki 1 so prikazani kreativni podsektorji glede na upad prihodkov v letih 2019 in 2020.

Slika 2: SPREMEMBA PRIHODKOV V LETIH 2019 IN 2020 (V\%) - PRIMERJAVA LETA 2019 Z OCENAMI POMLADI IN JESENI 2020

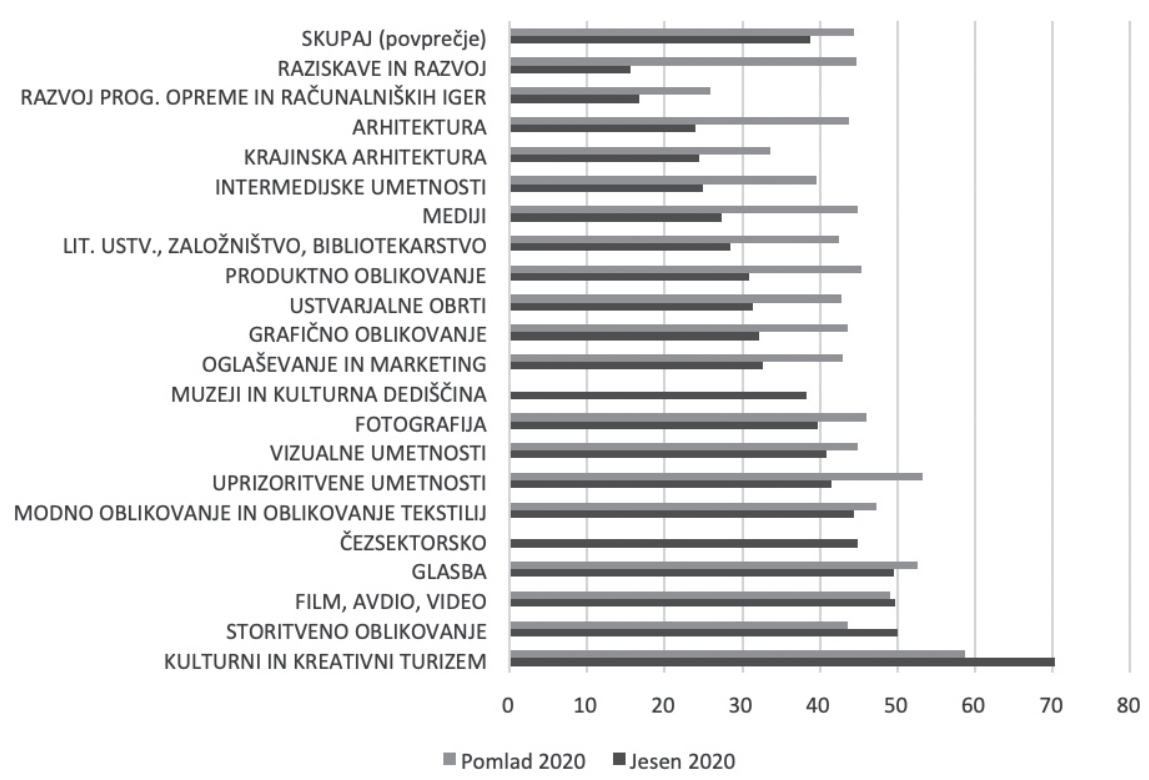

Vir: Matjaž et al., 2020.

Iz podatkov je lepo razvidno, kateri sektorji so utrpeli največji upad dela in prometa $\mathrm{v}$ obdobju pandemije. Največji vpliv pandemije so glede na podatke občutili kreativni podsektorji, ki so vezani na delo v prostoru oz. 
na fizični lokaciji. Podsektorji, kot so na primer kulturni in kreativni turizem in uprizoritvene umetnosti, so primarno odvisni od delovanja na določeni lokaciji, v stavbi ali specifičnem prostoru, pri čemer zapora teh prostorov samodejno pomeni tudi nezmožnost opravljanja določenih dejavnosti. Lepa ponazoritev tega problema je izražena skozi odprta vprašanja, ki smo jih omogočili v okviru raziskave in nazorno razkrivajo zagate nastale situacije:

Naša dejaunost je izvedba prireditev. Ozvočenja, osvetlitve, postavitev odrov, konstrukcij. 7. marca smo imeli prvi prepovedan koncert v dvorani Bonifika $v$ Kopru in nato vse ostale. (Odprta vprašanja, Matjaž et al., 2020)

in:

Nobena stvar ne poteka tako kot pred krizo. Razstave se zamenjajo brez otvoritev.

Slika 3 še bolj nazorno ponazarja navedeno situacijo omejenih zmožnosti izvajanja dejavnosti, ki so vezane na določene prostore med epidemijo 772 Covida-19.

Slika 3: NAČIN IZVAJANJA AKTIVNOSTI V OBDOBJU PANDEMIJE

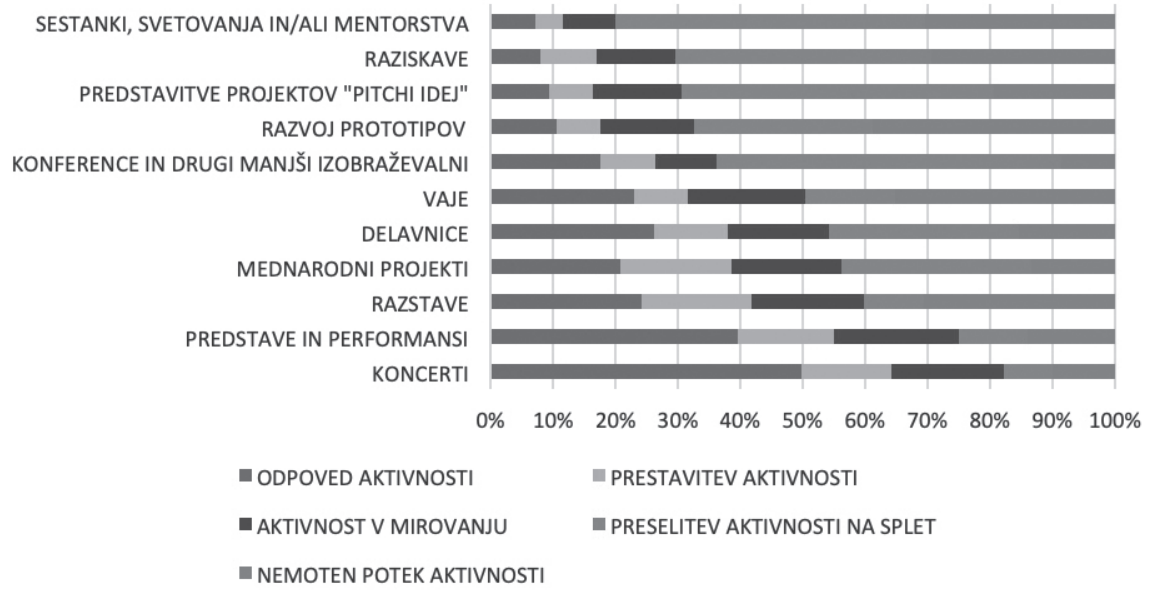

Vir: Matjaž et al., 2020.

Iz navedene strukture dejavnosti je jasno razvidno, katere vrste kreativnih dejavnosti so bile z uvajanjem pandemičnih ukrepov, ki zahtevajo strogo uvajanje fizične distance in prepoved zbiranja, najbolj omejene. Pri 
tem so določeni tipi dejavnosti, kot so na primer koncerti (odpovedanih ali prestavljenih je bilo $65,2 \%$ teh aktivnosti) ali predstave (55,1\% teh dejavnosti je bilo prestavljenih ali odpovedanih), performansi in razstave, v največji možni meri vezane na fizično izvajanje, preostale dejavnosti pa zelo vezane na kontekst oz. kreativni milje in ustvarjanje ustrezne atmosfere, ambienta, interakcijskega procesa, kar vse predstavlja platformo, na kateri potekata kreativni proces in produkcija. Nekatere dejavnosti (npr. sestanki, svetovanja in/ali mentorstva) so kljub pandemiji svoje aktivnosti v okrnjeni izvedbi še vedno izvajale prek drugih nefizičnih načinov (npr. preselitev aktivnosti na splet), pri čemer se ne ve natančno, kakšne bodo posledice teh sprememb. Slika 4 ponazarja, kako so podsektorji, ki so v večji meri vezani na uporabo digitalnih orodij za izvajanje svojih storitev, v obdobju pandemije pridobili velik pomen. Pri tem se je na primer relativno velikemu delu zaposlenih v podsektorju »razvoj programske opreme in računalniških iger«zelo zvišal mesečni dohodek.

\section{Slika 4: REDNI MESEČNI DOHODEK V PRIMERJAVI Z OBDOBJEM PRED PANDEMIJO COVIDA-19 (V\%)}

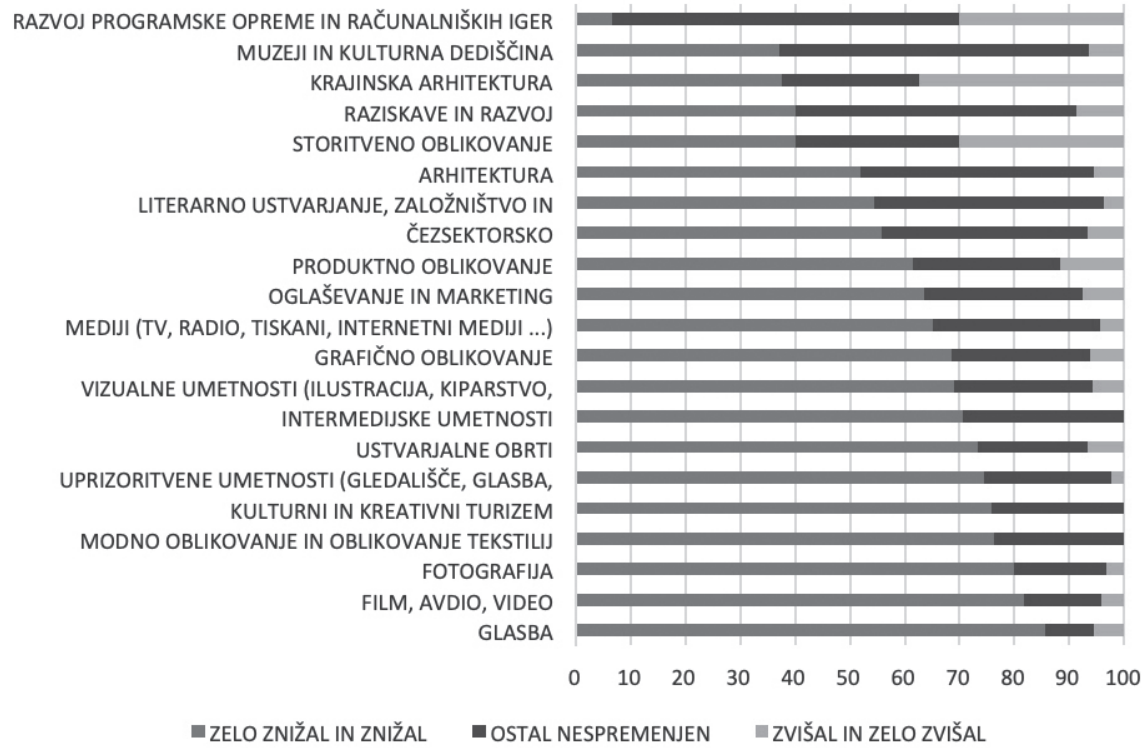

Vir: Matjaž et al., 2020.

Kljub temu da so nekateri kreativni sektorji z učinkom pandemije pridobili na tržni vrednosti oz. si povišali dohodke (glej sliko 3), pa je zaenkrat jasno, da največji delež kreativnega sektorja utrpel velike izgube. $\mathrm{Ob}$ hkratnem povečanju prihodka v nekaterih podsektorjih se je namreč veliki 
večini zaposlenih v kreativnem sektorju zmanjšal prihodek. Velja omeniti, da je $78,5 \%$ zaposlenih v celotnem kreativnem sektorju ocenilo, da so se prihodki znižali, ob čemer jih je 34,7\% menilo, da so se zelo znižali. Najbolj so znižanje prihodkov občutili v podsektorjih uprizoritvenih umetnosti (v obdobju marec-september 2020 je tako ocenilo kar 91,3\% zaposlenih v tem podsektorju), sledijo fotografija (88,2\%), glasba (87,5\%), kulturni in kreativni turizem (87,5\%), film (83,3\%) in tako dalje. Še več, zdi se, da skladno $s$ prestrukturiranjem aktivnosti $v$ smeri vse večje digitalizacije prihaja tudi do pomembnih stranskih učinkov, ki vodijo v krčenja obsega dejavnosti posameznih podsektorjev. Krčenje obsega dejavnosti določenih kreativnih podsektorjev za krajše obdobje ne vpliva bistveno na kreativni ekosistem, bistveno drugače pa je, če se ob zmanjševanju obsega dejavnosti sistemsko prestrukturira delovanje kreativnega ekosistema. Pod sistemsko prestrukturacijo je mišljena sprememba razmer, $v$ katerih se producirajo in izvajajo storitve v določenem sektorju. Sprememba pogojev delovanja lahko prinaša določene kratkoročne pozitivne učinke, kot so na primer digitalizacija in delitvene ekonomije $\mathrm{v}$ smislu dostopnosti, poenostavitve ter ažurnosti storitev kreativnega sektorja, precej nejasni pa so njihovi dolgoročni učinki na strukturo delovnih pogojev kreativnih zaposlenih, kakovost življenja in 774 delovanje kreativnega miljeja nasploh.

Odprta vprašanja v raziskavi (Matjaž et al., 2020) so pomagala identificirati šest bistvenih problemov, ki so vplivali na slabše poslovanje med pandemijo Covida-19 in so povezani s spremembami pogojev delovanja. Glede na pogostost odgovorov so razvrščeni od bolj pogostih k manj pogostim: manjše povpraševanje, ustavitev izvedb bodisi zaradi ustavitve življenja med epidemijo bodisi zaradi prestrogih ukrepov, manj možnosti navezovanja novih poslovnih stikov, več dela za enak zaslužek in naraščajoča plačilna nedisciplina, neplačevanje in zavlačevanje plačil (Matjaž et al., 2020: 25). V kontekstu prestrukturacije pogojev velja omeniti zlasti tretji najpogosteje omenjeni razlog, tj. manj novih poslovnih stikov, ki je neposredno povezan z delovanjem kreativnega miljeja in je en od ključnih značilnosti prekarizanih življenjskih stilov kreativnih zaposlenih, ki prek elementov neformalnosti ohranjajo iluzijo delovnega in bivanjskega ravnovesja. Kot je nazorno ilustriral odgovor enega izmed vprašanih v raziskavi, ki opozarja na pomanjkanje zmožnosti ustvarjanje socialnih omrežij (ibid.):

Delo, ki ga opravljam, temelji tudi na neformalnih odnosih in Covid je zelo vplival na ta segment, ki je pomemben za dogovarjanje za prihodnje projekte, za sporazumevanje in uspešno sodelovanje. Več je distance, izogiba se vsemu, kar ni 'nujen stik', vendar je ravno ta neformalni stik in odnos pomemben za mreženje. 


\section{Analiza vpliva pandemije na kreativne življenjske stile}

V nadaljevanju bomo podrobneje analizirali kontekst pandemije, $v$ katerem delajo in živijo kreativci, nato pa iz tega ekstrapolirali problematične trende nadaljevanja in stopnjevanja prekarizacije, ki hipotetično zmanjšuje kreativno zmogljivost slovenskega kreativnega ekosistema. Ob tem predpostavljamo, da so omejitve, ki izvirajo iz pandemije Covida-19, drastično vplivale ne le na obseg dela, temveč so še pomembneje spreminjale življenjske stile in kakovost življenja zaposlenih v kreativnih dejavnostih. Kontekst okoliščin, v katerih so se znašli kreativni zaposleni, dobro ponazarja podatek o problemih, povezanih z delovnimi prostori (slika 5).

Slika 5: ALI STE SE Z NAJEMODAJALCEM DOGOVORILI O ZMANJŠANI NAJEMNINI DELOVNIH PROSTOROV V ČASU PANDEMIJE COVIDA-19?
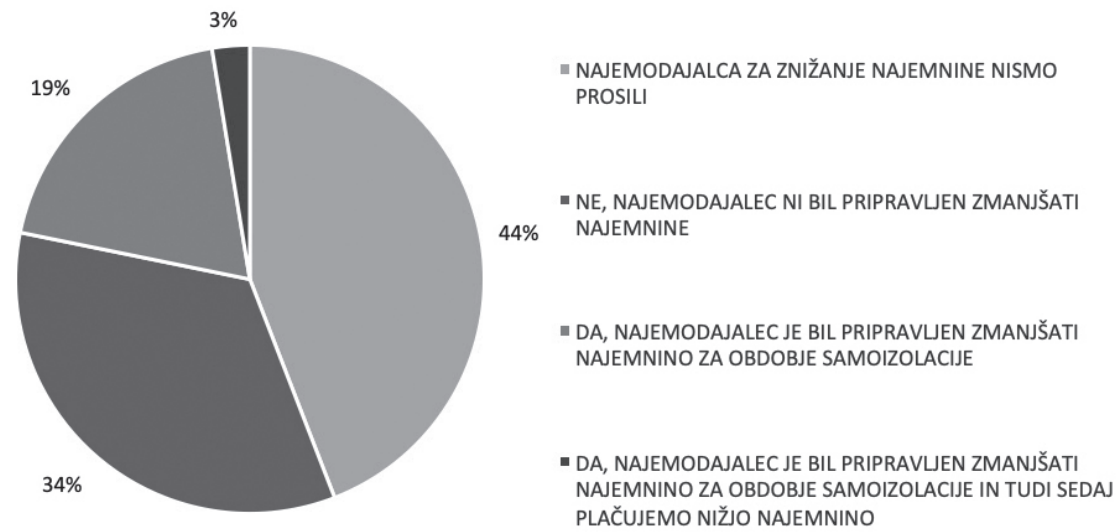

Vir: Matjaž et al., 2020.

Delovni prostori predstavljajo osnovno obliko delovne avtonomije kreativnih zaposlenih in so ključni element življenjskostilskih formacij, vezanih na produkcijo kreativnosti. Podatki kažejo, da v času pandemije pri pomembnem deležu najemnikov prostorov za kreativne dejavnosti s strani najemodajalcev ni prihajalo do omilitve stroškov in cene najema. Le približno 21,8\% najemodajalcev je bilo pripravljeno znižati najemnino, medtem ko 34,1\% najemodajalcev ni bilo naklonjeno tem pobudam. Pri tem je moralo 4,1\% vseh vprašanih v vzorcu 1578 oseb zaradi pandemije odpovedati najem poslovnih prostorov. Še bolj ilustrativni so podatki o tem, kako se je pandemija spreminjala kontekst načina dela. Raziskave kažejo (npr. Lorentzen, 2007; Horning, 2010; Kuster in Tsianos, 2011), da je za kreativno sfero značilno veliko prepletanje vsakdanjih življenjskih aktivnosti, socialnih omrežij in samega dela. Prepletanje zasebnosti in prostočasnih 
aktivnosti z delovnim procesom omogoča zelo specifičen nerutiniziran način produkcije $v$ kreativnih dejavnostih, pri čemer so razmerja med periodami dela, prostočasnih aktivnosti in zasebnih (družinskih) aktivnosti zelo občutljivo uravnotežena. Pandemija je $\mathrm{v}$ ta razmerja zelo posegla, kar se na primer zrcali iz podatkov raziskave, opravljene v okviru Kreativnega centra Poligon in Muzeja za arhitekturo in oblikovanje (Matjaž et al., 2020), ki kažejo na spremembo lokacije dela (slika 6).

Slika 6: KAKO SI DELAL PRED PANDEMIJO - KAKO DELAS̆ DANES (V\%)?

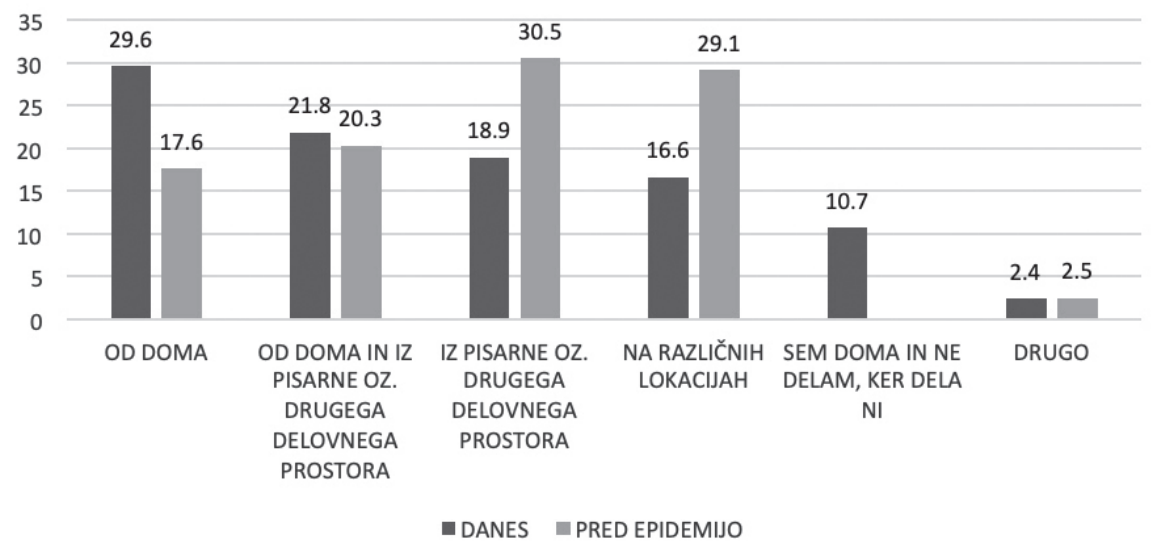

Vir: Matjaž et al., 2020.

Kljub temu da kreativne dejavnosti temeljijo na fleksibilnosti dela, pa vendarle obstajajo izmenjujoče se periode med obdobji dela, počitka in zasebnih aktivnosti. Pri tem velja opozoriti, da je ta preplet oz. možnost fleksibilnega ločevanja javnega in zasebnega še posebej za kreativne zaposlene posebnega pomena zaradi dejavnika neformalnosti v delovnih in življenjskih odnosih (Lorentzen, 2007; Horning, 2010). Pandemija je porušila ta razmerja in sprožila procese mešanja zasebnega in delovnega okolja do mere, ki je zahtevala dodatne obremenjujoče prilagoditve kreativnih zaposlenih. S tem ko so zaposleni vse bolj delali od doma, se je nižala delovna učinkovitost (55,6\% vprašanih ocenjuje, da je ta nižja kot pred pandemijo), slabšale pa so se tudi druge razmere za uspešno opravljanje kreativnih dejavnosti. Med omenjenimi vzroki nižje delovne učinkovitosti so: »oteženo načrtovanje, težja izvedba programov zaradi pandemičnih omejitev, problem socialne komunikacije prek digitalnih orodij, naporno usklajevanje dela in gospodinjenja, slabša organizacijska klima in nesorazmerna delovna obremenitev« (Matjaž et al., 2020: 31). Kljub navajanjem tudi posameznih pozitivnih aspektov pandemije, ki je v določenih elementih (omenjeni so 
npr. povečanje prilagodljivosti, delovna učinkovitost, bolj umirjen delovni tempo, udobje dela od doma in povečanje solidarnosti) vplivala tudi na povišanje delovne učinkovitosti, je potrebno omeniti, da je razmerje med koristnimi in škodljivimi elementi pandemičnega konteksta za kreativno produkcijo nedvomno obrnjeno v smer pretežno problematičnih značilnosti delovnega procesa, ki pospešujejo proces prekarizacije (in ga ne zmanjšujejo). To se kaže tudi prek podatkov na sliki 7 , ki prikazuje nadomeščanje finančnega primanjkljaja z iskanjem alternativnih rešitev.

\section{Slika 7: ALI SE ZA PREMOSTITEV FINANČNE STISKE POSLUŽUJE ̌̌ ŠE KATERIH DRUGIH OBLIK POMOČI?}

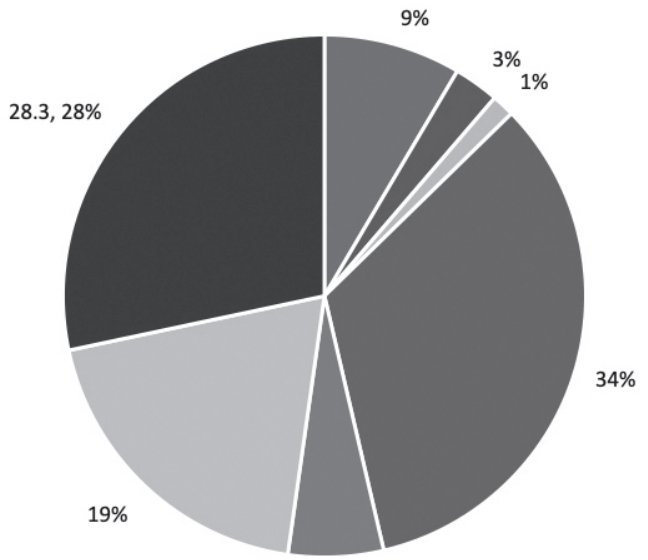

$6 \%$

\author{
- SOCIALNE POMOČI OB BREZPOSLENOSTI \\ - IZREDNE (ENKRATNE) SOCIALNE POMOČI \\ - PREMOSTITVENE POMOČI AKCIJE \\ SOLIDARNI S KULTURO \\ - POSOJILA OD KOLEGOV, SORODNIKOV ALI \\ PRIJATEUEV \\ - DRUGA POMOČ \\ - DRUGIH OBLIK POMOČI SE ŠE NISEM \\ POSLUŽILA, A SE JIH ŠE NAMERAVAM \\ - DRUGIH OBLIK POMOČI SE NE \\ NAMERAVAM POSLUŽITI
}

Vir: Matjaž et al., 2020.

Podatki prikazujejo, kako so se kreativni zaposleni v obdobju pandemije posluževali različnih strategij za premoščanje finančne stiske. Najpogosteje uporabljan ukrep je uporaba skladov, ki izvirajo iz akcije "Solidarni s kulturo« (RKS, 2020). Pri tem velja omeniti, da so bili vprašani, med katerimi je večina zaposlena $v$ zasebnem sektorju (odvisnost financiranja vprašanih od javnih razpisnih sredstev je nizka, zgolj 29,6-odstotna, kar izpodbija ustaljena prepričanja o veliki odvisnosti tega sektorja od javnega denarja), izjemno kritični do ukrepov vlade. Kot so pojasnjevali v odprtih vprašanjih, vlada v nezadostni meri, predvsem pa izjemno nesistematično podpira zgolj posamezne dele kreativnega sektorja:

Ukrepi so selektivno usmerjeni predvsem v zaščito določenih sektorjev, npr. turističnega, na področju kulture in kreative pa ne poznam nobenih ciljnih ukrepov. (Odprta vprašanja, Matjaž et al., 2020) 
Po podatkih iz raziskave $19,5 \%$ zaposlenih v kreativnih dejavnostih ni prejela (ni bila upravičena do) državne pomoči, nadaljnjih 23,2\% pa navaja, da so pomoč prejeli, vendar je le ta bila nezadostna. Pri tem je iz odprtih vprašanj razvidno, da tudi prejemniki državne pomoči opažajo določene probleme, ki so povezani s slabo pripravljeno državno strategijo pomoči pri okrevanju gospodarstva:

Čeprav sem prejela državno pomoč, ki mi je $v$ dveh mesecih leta 2020 pomagala premestiti poslovne težave, bom to pomoč v letu 2021 zaradi povsem nečloveških in nesmiselnih pogojev tudi vračala ... in se po vsej verjetnosti takrat ponouno znašla v finančni stiski ... (Odprta vprašanja, Matjaž et al., 2020)

Ukrepi so vse preveč usmerjeni na trenutno pomoč in le na mesece, ko je bila razglašena pandemija (marec, april, maj). Ker sodelujem s festivalom, za katerega se mi zdi, da še vsaj dve leti ne bo stopil na stare tirnice, bomo imeli tisti, ki sodelujemo z organizatorji dogodkov, po oceni večji upad dohodka šele v letih 2021 in 2022 ... (Odprta vprašanja, Matjaž et al., 2020)

Kontekst pandemije je zaradi kombiniranja različnih razlogov vplival na nadaljnjo prekarizacijo in slabšanje življenjskih razmer kreativnih zaposlenih, ki so navajali sledeče psiho-socialne situacije in ekonomske stiske: strah in tesnoba zaradi nakopičenih problemov, izčrpanost, občutek nesmisla opravljanja obstoječe dejavnosti, osamljenost (izoliranost), varčevalni ukrepi v zasebnem življenju, plačevanje rednih računov (najemnina), zadolževanje in postopno drsenje v revščino. Spodaj je navedenih še nekaj izsekov iz odprtih vprašanj, ki ponazarjajo problematičnost razmer (npr. psihična izčrpanost, iskanje nadomestnih poklicev, finančna stiska), v katerih so se znašli kreativni zaposleni:

V obdobju prvega 'lockdowna' je še nekako šlo, zdaj pa smo že vedno bolj izčrpani in ne več toliko optimistični ...

Moja izkušnja nedela je zelo garaška. Enormno se je povečalo gospodinjsko, neplačano delo...

Včasih celo razmišljam, da bi bilo bolj fiksno, varno in smiselno, če grem obirat jabolka ali pa pomagat na kmetijo, ker se to potrebuje. Pa vendar je to le misel, moje poslanstvo je v kulturi in tudi to je hrana za ljudi... 
Račune za televizijo, internet, telefon sem skrčila na minimum: zamenjala naročniške pakete, hrano skrčila na najnujnejše prehranjevanje, oblačil ne kupujem več, plačljivo zobozdravstveno storitev sem ukinila

\section{Sklep}

Neenakosti in prekarni odnosi, ki se pojavljajo v okviru kreativnih dejavnosti, so manj opazna tematika analiz, ki se ukvarjajo z delovanjem ekonomskih sistemov. Kreativni zaposleni so vezivno tkivo ostalih ekonomskih sektorjev, prek svojih dejavnosti in specifičnega prekarnega načina dela zapolnjujejo pomembne produkcijske niše $\mathrm{v}$ širšem ekonomskem sistemu. Kontekst pandemije je že pregovorno prekarno področje kreativnih zaposlitev še dodatno poglobil. S tem pritrdilno odgovarjamo na zastavljeno raziskovalno vprašanje, ki je bilo usmerjeno v potencialno tvorjenje novih elementov prekarizacije kreativnih zaposlenih. V članku smo na podlagi podatkov iz raziskave identificirali in analizirali nove elemente prekarnosti, ki so jih sprožile pandemične razmere. Analizirani podatki nazorno prikažejo, kako so ukrepi, povezani z omejevanjem širjenja pandemije Covida-19, vplivali na nadaljevanje procesov prekarizacije $v$ večini segmentov kreativnih poklicev. Pri tem je iz podatkov opazno, da imajo oz. bodo imeli s pandemijo povezani procesi prekarizacije širši, globlji in dolgoročnejši vpliv na nadaljnje delovanje kreativnega sektorja. Izsledki analize odgovarjajo na raziskovalno vprašanje o vplivu pandemije na nadgradnjo obstoječih oblik kreativnih prekarnosti, kar lahko strnemo v naslednje zaključke:

Prvič, z vidika procesa prekarizacije je imela pandemija še posebej močan vpliv na določene kreativne podsektorje (npr. film, uprizoritvene umetnosti, kulturno-kreativni turizem), ki so izrazito vezani na delo na lokaciji. Pri tem je treba poudariti, da pomen lokacije za določene kreativne podsektorje ne temelji zgolj na geografski dimenziji, temveč zlasti na socialni kreativnosti, ki je vezana na določen kreativni milje, ki se je skozi daljše časovno obdobje izoblikoval na tej lokaciji. S tega vidika so v pandemičnem obdobju največjo škodo utrpeli podsektorji, ki so produkcijsko vezani na socialno kreativnost (npr. film, uprizoritvene umetnosti, kulturni in kreativni turizem itd.). Te kreativne podsektorje bi bilo v kontekstu obstoječe in prihodnje finančne pomoči potrebno bistveno bolj izrazito razplastiti v odnosu do drugih podsektorjev, ki niso tako fizičnoprostorsko vezani. Ti sektorji so ključnega pomena tudi za vnovično vzpostavljanje storitev, servisov, delovanja javnih prostorov, ki so povezani z dogodkovnostjo, ohranjanjem socialnega kapitala in socialnih mrež ter mestnih ekonomij, povezanih s kakovostjo življenja. 
Drugič, fleksibilizacija v smislu izvajanja delovnega procesa se je za kreativne podsektorje, ki lahko delujejo na daljavo, v obdobju pandemije izrazito povečala. Kljub temu da so se prilagoditve dela med pandemijo zgodile v vseh ekonomskih sektorjih, je v kontekstu kreativnih dejavnosti to še posebnega pomena zaradi izrazito lokacijske in družbeno-kulturne naravnanosti omenjenega sektorja. Pri tem podatki kažejo, da gre za obliko fleksibilnosti, ki zahteva določene prilagoditve v življenjskem stilu zaposlenih. Skladno z večjo fleksibilnostjo v delovnem procesu se je namreč povečala tudi prepletenost delovnega procesa z drugimi življenjskimi aktivnostmi kreativnih zaposlenih (npr. družina, prostočasne aktivnosti), kar je vodilo $\mathrm{v}$ preoblikovanje ločnic med zasebnim in javnim delovanjem posameznikov in posledično sprožalo tudi določene napetosti v delovnem procesu. Odprava oz. zamrznitev, omejevanje delovanja fizičnega kreativnega miljeja kot platforme, na kateri temelji izmenjava informacij, socialnih vezi, neverbalnih komunikacij, je v tem pogledu - kljub večji fleksibilnosti opravljanja dela na daljavo - pri večini kreativnih podsektorjev vodila v zmanjšanje obsega socialnih omrežij, manjši pretok informacij, zmanjševanje kulturnega in socialnega kapitala kreativnih zaposlenih. To je lepo razvidno iz podatkov o vzrokih nižje delovne učinkovitosti.

Tretjič, pandemija je prek pospešenega uvajanja digitalizacije oz. dela na daljavo nedvomno zelo vplivala na delovanje celotnega kreativnega sektorja. Podatki o spremembah dohodkov kreativnih zaposlenih v obdobju pandemije kažejo, da so nekateri podsektorji (npr. razvoj programske opreme in računalniških iger) s finančnega vidika močno pridobili na pomenu. Tovrstne spremembe bodo zaradi fleksibilnosti, ki jih ponuja digitalizacija, nedvomno v bistveno večji meri prisotne tudi po koncu pandemije. Sprememba v hierarhiji pomembnosti posameznih kreativnih podsektorjev bo neizbežno vplivala na prestruktiranje celotnega sektorja, kar bo sprožalo nadaljnje procese prekarizacije posameznih podsektorjev, ki se na videz zdijo manj pomembni za delovanje ekonomskega sistema. Pri tem se porajajo pomembna vprašanja, kako/ali bodo odločevalci ohranjali delovanje pomembnih podsektorjev, ki opravljajo pomembne funkcije generiranja socialnega kapitala, omogočajo sinergije in medsektorsko povezovanja ter na dolgi rok povečujejo kreativno zmogljivost mesta, regije in države. Družbeno-ekonomski učinek posameznih kreativnih podsektorjev se v tem kontekstu ne meri z vidika direktnih finančnih učinkov, ki jih zagotavlja kreativna sposobnost, temveč tudi prek kakovosti življenja, socialne kreativnosti in dolgoročne kreativne zmogljivosti mesta.

Zmanjšanje obsega delovanja določenih kreativnih podsektorjev in pomena fizičnega kreativnega miljeja postopoma ustvarja slabše pogoje tudi za delovanje podsektorjev, ki se na prvi poglej ne zdijo veliko povezani z omenjenimi problemi. Raziskave kažejo (Giaccardi in Fischer, 2008; 
Meusburger, 2009; Rivas, 2011; Uršič in Imai, 2020), da so vsi kreativni podsektorji na vrsto načinov zelo povezani z uporabo določenih fizičnih lokacij, ki služijo kot platforma za osebno rast, izmenjavo in širitev stikov, informacij, znanja, opravljanja prostočasnih aktivnosti s podobno mislečimi. S tega vidika se pomen lokacije in fizičnega prostora $\mathrm{v}$ smislu zagotavljanja konteksta za izvajanje kreativnih aktivnosti ne zmanjšuje, ampak celo pridobiva pomen $v$ smislu ohranjanja socialnih omrežij in akumulacije socialnega kapitala. Z drugimi besedami, selitev dela aktivnosti kreativnega sektorja na digitalne platforme morda res zvišuje delovno učinkovitost in omogoča opravljanje storitev $\mathrm{v}$ kratkih obdobjih, a tovrstna orodja ne morejo nadomestiti fizičnega kreativnega miljeja, ki zagotavlja druge nujne kvalitete za delovanje kreativnega ekosistema. Sistemsko (dolgoročno) zmanjševanje pomena fizičnega kreativnega miljeja vodi $v$ homogenizacijo kreativnih skupin in zmanjševanje heterogenosti ter socialnega kapitala, znanj, izkušenj in omrežij, kar zmanjšuje privlačnost (kakovost življenja) mest, regij in držav za določene skupine kreativnih zaposlenih in se dolgoročno kaže v postopnem zmanjševanju ali počasnejšem naraščanju ekonomskega obsega teh dejavnosti.

\section{LITERATURA}

Bairoch, Paul (1998): Cities and Economic Development. Chicago: University of Chicago Press.

Colomb, Claire, Johannes Novy (2018): Protest and Resistance in the Tourist City. Abingdon, Oxon; New York, NY: Routledge.

Cunningham, Stuart, Peter Higgs (2009): Measuring Creative Employment: Implications for Innovation Policy. Innovation 11 (2): 190-200.

Cunningham, Stuart (2013): Hidden Innovation: Policy, Industry and the Creative Sector. St Lucia, Queensland: University of Queensland Press.

De Carolis, Massimo (1996): Toward a phenomenology of opportunism. V: Virno, Paolo, Hardt, Michael (ur.): Radical thought in Italy: A potential politics, 37-52. Minneapolis: University of Minnesota Press.

de Peuter, Greig (2011): Creative Economy and Labor Precarity: A Contested Convergence. Journal of Communication Inquiry 35 (4): 417-425.

Ferreri, Mara, Valeria Graziano (2014): Passion without Objects. Young Graduates and the Politics of Temporary Art Spaces. Recherches sociologiques et anthropologioques 45 (2): 85-101.

Fischer, Gerhard (2013): Learning, Social Creativity, and Cultures of Participation. V: Annalisa Sannino (ur.): Learning and Collective Creativity: Activity-Theoretical and Sociocultural Studies, 198-215. London, New York: Routledge.

Florida, Richard (2002): The Rise of the Creative Class. New York: Basic Books.

Florida, Richard, Gary Gates, Brian Knudsen, Kevin Stolarick (2006): The University and the Creative Economy. Portland, OR: Creative class group.

Giaccardi, Elisa in Gerhard Fischer (2008): Creativity and Evolution: A Metadesign Perspective. Digital Creativity 19 (1): 19-32. 
Glaser, Barney G. (1998): Doing Grounded Theory: Issues and Discussions. First printing. Mill Valley: Sociology Press.

Gray, Anne (2004): Unsocial Europe: Social protection or flexploitation? London: Pluto.

Gunnell, Barbara, Martin Bright (2011): Make a Job Don't Take a Job. Building the Creative Society TM. London: New Deal of the Mind.

Hardt, Michael, Antonio Negri (2004): Multitude: War and democracy in the age of empire. New York, NY: Penguin.

Hearn, Greg (2014): Creative Occupations as Knowledge Practices: Innovation and Precarity in the Creative Economy. Cultural Science Journal 7 (1): 83.

Hesmondhalgh, David (2002): The Cultural Industries. London: Sage.

Horning, Rob (2010): Death of the Hipster. V: Greif, Mark; Ross, Kathleen; Tortorici, Dayna (ur.). What Was the Hipster? A Sociological Investigation, 82-93. New York: $\mathrm{n}+1$ Foundation/HarperCollins.

Holt-Jensen, Arild (1988): Geography: History and Concepts. 2nd ed. London: Paul Chapman.

Howkins, John (2001): The creative economy: how people make money from ideas. London: Penguin Books.

Klausmeier, Herbert J. (1961): Learning and Human Abilities: Educational Psychology. 3d ed. New York: Harper \& Row.

Kong, Lily (2011): From precarious labor to precarious economy? Planning for precarity in Singapore's creative economy. City, Culture and Society 2: 55-64.

Kozina, Jani, Nick Clifton (2019): City-Region or Urban-Rural Framework: What Matters More in Understanding the Residential Location of the Creative Class? Acta Geographica Slovenica 59 (1): 141-157.

Kuster, Brigitta, Vassilis Tsianos (2011): Experiences Without Me, or, the Uncanny Grin of Precarity. V: Raunig, Gerald, Ray, Gene, Ulf Wuggenig (ur.): Critique of Creativity: Precarity, Subjectivity and Resistance in the 'Creative Industries', 91-101. London: MayFlyBooks.

Landry, Charles, Franco Bianchini (1995): The Creative City. London: Demos.

Lazzeretti, Luciana (2012): The Remarkable Resilience of Florence, City of Art (Regional Studies Association European Conference Networked regions and cities in times of fragmentation: Developing smart, sustainable and inclusive places). Delft: Delft University of Technology.

Long, Haiying, Weiguo Pang (2015): Rater Effects in Creativity Assessment: A Mixed Methods Investigation. Thinking Skills and Creativity 15: 13-25.

Lorey, Isabell (2011): Virtuosos of Freedom: On the Implosion of Political Virtuosity and Productive Labour. V: Raunig, Gerald, Ray, Gene, Ulf Wuggenig (ur.): Critique of Creativity: Precarity, Subjectivity and Resistance in the 'Creative Industries', 79-90. London: MayFlyBooks.

Matjaž, Eva, Polona Černič, Teja Kosi (2020): Slovenski kulturno-kreativni delavec v času Covid-19. Ljubljana: Poligon, MAO.

Meusburger, Peter (2009): Milieus of Creativity: The Role of Places, Environments, and Spatial Contexts. V: Peter Meusburger, Jachim Funke, Edgar Wunder ur.): Milieus of Creativity 2: 97-153. Dordrecht: Springer Netherlands. 
Minichbauer, Raimund (2005): Pure policy: EU cultural support in the next 10 years. V: Lind, Maria, Raimund Minichbauer (ur.): European Cultural Policies, 91-109. Vienna, eipcp.

Montouri, Alfonso in Ronald Purser (1997): Social Creativity: The Challenge of Complexity (Le Dimensioni Sociali Della Creatività). Pluriverso 1 (2): 78-88.

Murovec, Nika, Damjan Kavaš, Tjaša Bartol (2020): Statistična analiza stanja kulturnega in kreativnega sektorja v Sloveniji 2008-2017. Ljubljana: Center za kreativnost, Muzej za arhitekturo in oblikovanje.

Pratt, Andy C. (2004): Creative Clusters: Towards the Governance of the Creative Industries Production System? Media International Australia Incorporating Culture and Policy 112 (1): 50-66.

Raunig, Gerald, Gene Ray, Ulf Wuggenig (2011): Critique of Creativity: Precarity, Subjectivity and Resistance in the 'Creative Industries'. London: MayFlyBooks.

Rivas, Miguel (2011): From Creative Industries to the Creative - Place Refreshing the Local Development Agenda in Small and Medium-Sized Towns. Paris: URBACT.

Ross, Andrew (2009): Nice Work If You Can Get it: Life and Labor in Precarious Times. New York: New York University Press.

Sailer, Kerstin (2011): Creativity as Social and Spatial Process. Facilities 29 (1/2): 6-18.

Scott, Allen (2000): The cultural economy of cities. London: Sage.

Tashakkori, Abbas, Charles Teddlie (2010): SAGE Handbook of Mixed Methods in Social \& Behavioral Research. Thousand Oaks: Sage Publications.

True, Sally (1966): A Study of the Relation of General Semantics and Creativity. The Journal of Experimental Education 34 (3): 34-40.

Ursic, Matjaz, Heide Imai (2020): Creativity in Tokyo: Revitalizing a Mature City. Singapore: Palgrave Macmillan, Springer.

Ursic, Matjaz, Wonho Jang, Kee-Bom Nahm (2018): Creative Precarity: Flexibilization of Working Conditions and Growth of Precarious Creative Employment in Slovenia and South Korea'. Annales: Anali za istrske in mediteranske študije = Annali Di Studi Istriani e Mediterranei $=$ Annals for Istrian and Mediterranean Studies. Series Historia et Sociologia 28 (4): 841-852.

Virno, Paolo (2004): A grammar of the multitude: For an analysis of contemporary forms of life. New York, NY: Semiotext(e).

von Osten, Marion (2007): Unpredictable outcomes/unpredictable outcasts: A reflection after some years of debates on creativity and creative industries. V: Lovink, Geert, Ned Rossiter (ur.): MyCreativity reader: A critique of creative industries, 49-58. Amsterdam: Institute of Network Cultures.

VIRI

BIG (2020): Kreativni barometer 2020: Ustvarjalnost 19 držav Jugovzhodne Evrope. Ljubljana: Zavod BIG.

Bologna, Sergio (2007): An invisible history of work: Interview with Sergio Bologna (Interviewed by S. Grimm \& K. Ronneberger; H. Ferguson, Trans.). Springerin, 1, 7. Dostopno prek https://metropolitanfactory.files.wordpress.com/2012/07/ an-invisible-history-of-work.pdf, 25. 11. 2015. 
Department for culture, media and sport (DCMS) (2001): Department for culture, media and sport. Dostopno prek Http://www.culture.gov.uk/index.aspx, 12. 9. 2012.

European Union (2010): The Green Book on cultural and creative industries. Brussels: European Union.

Lorentzen, Christian (2007): Kill the hipster: Why the hipster must die: A modest proposal to save New York cool. Dostopno prek https://www.timeout.com/ newyork, 28. 4. 2020.

RKS - Rdeči Križ Slovenije (2020): Solidarni s kulturo. Ljubljana: RKS-OZ Ljubljana, dostopno prek https://solidarniskulturo.org/, 10. 5. 2021.

UN - United Nations (2019): International Year of Creative Economy for Sustainable Development, 2021. UN, Resolution adopted by the General Assembly on 19 December 2019, dostopno prek https://undocs.org/en/A/RES/74/198, 10. 5. 2021.

United Cities and Local Governments (UCLG) (2008): Agenda 21 for culture. Barcelona: Committee on culture - United Cities and Local Governments, 2004. 